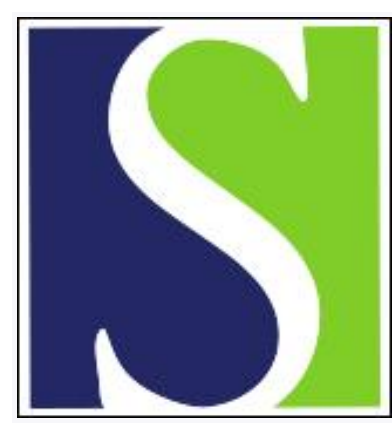

Scand J Work Environ Health 1995;21(1):30-35

https://doi.org/10.5271/sjweh.5

Issue date: Feb 1995

Dermatoses determined in a population of farmers in questionnaire-based clinical study including methodology validation

by Susitaival P, Husman L, Hollmén A, Horsmanheimo M

The following articles refer to this text: $2002 ; 28(6): 371-385$;

2019;45(5):450-457

Key terms: agriculture; epidemiology; hand eczema; skin disease

This article in PubMed: www.ncbi.nlm.nih.gov/pubmed/7784862

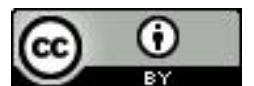




\title{
Dermatoses determined in a population of farmers in a questionnaire-based clinical study including methodology validation
}

\author{
by Päivikki Susitaival, MD, 'Liisa Husmant, MD, ${ }^{2}$ Antero Hollmén, MD, ${ }^{2}$ Maija Horsmanheimo, MD,2
}

\begin{abstract}
Susitaival $P$, Husman $L$, Hollmen A, Horsmanheimo M. Dermatoses determined in a population of farmers in a questionnaire-based clinical study including methodology validation. Scand J Work Environ Health 1995;21: $30-5$.
\end{abstract}

Objectives The study analyzed skin diseases in a population sample of Finnish farmers descriptively and in the process validated the question "Do you have a skin disease now?"

Methods All farmers from one Finnish municipality were surveyed for dermatoses, first with a questionnaire and then with a clinical examination of those who reported dermatoses. Another population of farmers answered a set of questions immediately before a clinical examination, and the self-report of current dermatosis was validated.

Results Eczema was diagnosed for $66 \%$ of the women and $53 \%$ of the men who had reported dermatosis in the questionnaire study 6 to 12 months earlier. Toe-web maceration, psoriasis, folliculitis, and acne were, after eczema, the most frequent diagnoses (in that order). In more than $50 \%$ of the cases, the location of clinically determined dermatoses corresponded with the skin disease areas reported 6 to 12 months earlier. In the validation study, everyone who reported a skin disease immediately before the clinical examination were found to have a skin disease. In addition $22 \%$ of those not reporting dermatosis were found to have a skin disease. Toeweb maceration was the most common dermatosis not reported by the farmers.

Conclusions Finnish farmers suffered from the same type of dermatoses as other populations. The prevalence of eczema and hand eczema was similar to that of other risk populations. A self-report of current dermatosis is probably a good indicator of the point prevalence of explicit skin diseases in populations.

Key terms agriculture, epidemiology, hand eczema, skin disease.

Some epidemiologic studies have been done on skin diseases in populations, including surveys among inhabitants of the Faroe Islands (1), United States inhabitants (2), Londoners (3), and Finnish Lapps (4). In Finland, a few skin disease surveys have been conducted also in occupational groups [eg, bricklayers (5), shipyard workers (6), workers in the food industry (7), and reindeer herders (8)].

No standardized validated questionnaires exist for epidemiologic studies in dermatology. Some epidemiologic studies of skin disease have also included methodology validation $(3,9-11)$, however, or have been designed for validation purposes $(12,13)$. There are neither uniform criteria nor standards for the definition of a case or a noncase of dermatosis or eczema in clinical studies or in postal surveys. Because, in most studies, the primary screening of the cases is an inquiry (postal or inter- view), it is critical to know the sensitivity and specificity of the method used.

The present study, being a part of a large epidemiologic investigation of dermatoses among farmers, is a descriptive analysis of skin diseases in the farming population of a Finnish municipality (Pielavesi). In addition, the validation of a "self-diagnosis" of current dermatosis ("Do you have a skin disease now?") in a questionnaire was included in the study. Information on the validity of answering this question is important for epidemiologic surveys of skin diseases. The answer serves as a simple screening method for further examinations and also as a means of estimating the point prevalence of skin diseases in population studies.

The analysis and publication of the data were delayed because of the death of the principal researcher $(\mathrm{LH})$ after the data collection.

1 Kuopio Regional Institute of Occupational Health, Kuopio, Finland.

2 Department of Dermatology, University of Kuopio, Kuopio, Finland.

Reprint requests to: Dr Päivikki Susitaival, Kuopio Regional Institute of Occupational Health, PO Box 93, FIN-70701 Kuopio, Finland. 


\section{Subjects and methods}

In December 1979 a questionnaire regarding health and work was sent to a population of Finnish farmers including all registered farmers between the ages of 18 and 64 years in two municipalities (A and B) (14). Most of the farmers in these two municipalities were involved in dairy farming. The questionnaire contained the question "Do you have a skin disease now?" The positive answers to this question gave the point prevalence of current skin diseases. The men and women with a positive answer were asked to indicate their dermatosis areas by shading them on a picture of a person. The hand and the forearm were together in the same area.

\section{Skin diseases in a dairy farming municipality}

In municipality A, 962 farmers (514 men and 448 women) out of $1052(95 \%)$ responded to the questionnaire in 1979. All of those reporting a "skin disease now" (88 men and 102 women) were invited to a clinical examination (history of skin disease and inspection always, skin prick tests, patch tests, and additional laboratory investigations when needed) at a department of dermatology in a university hospital. Altogether $73 \%$ of those reporting skin disease (64 men and 74 women) attended. They were examined by two dermatologists ( $\mathrm{LH}$ and $\mathrm{AH}$ ). The examination took place 6 to 12 months after the questionnaire survey, either in April to May or September to October 1980. The main farming operation of $85 \%$ of the surveyed population was dairy farming, and the figure was similar $(86 \%)$ for the examined farmers. The mean age of the examined farmers was 44.5 (10.9 SD) years for the men and 44.5 (10.1 SD) years for the women.

\section{Validation study}

For the validation study, both those with dermatoses and those without were needed. Therefore, from municipality
$\mathrm{B}$, a random sample of those reporting no dermatosis and another random sample of those reporting hand dermatosis in the questionnaire in 1979 were invited to visit the municipal health care center for a "health check," without them being informed that the examination concerned skin diseases. From the first group, 69 men and 53 women and, from the second group, 13 men and 28 women attended. The examination took place 16 months after the questionnaire survey. Before the examination, the farmers answered a short set of questions, including the following: "Do you have a skin disease now?" Immediately thereafter their skin was examined by a dermatologist (LH).

In analyzing the data, cross-tabulation and a chisquare test were used.

\section{Results}

\section{Skin diseases in a dairy farming municipality}

Among the farmers of municipality A the point prevalence of self-reported skin diseases (current skin disease) was $17.1 \%$ for the men and $22.8 \%$ for the women. The point prevalence of hand dermatoses was $4.1 \%$ for the men and $14.1 \%$ for the women.

The self-reported dermatosis areas on the farmers attending and on those not attending the examination are listed in table 1 . There were differences in the attendance by the reported area of dermatosis in the questionnaire (table 1). Most of those with hand dermatoses attended the examination. There were no significant differences in the farming operation, size of farm, atopy, or age between the examined and the unexamined farmer groups.

The location of the self-reported dermatoses and the later clinically diagnosed dermatoses is presented in table 2. For $70 \%$ of the farmers reporting skin disease on their hands in the questionnaire, dermatosis involving their hands was found in the clinical examination 6 to 12

Table 1. Principal area of dermatosis (questionnaire survey) on the clinically examined farmers and those who did not come to the examination.

\begin{tabular}{|c|c|c|c|c|c|c|c|c|}
\hline \multirow{3}{*}{$\begin{array}{l}\text { Self-reported principal } \\
\text { area of dermatosis }\end{array}$} & \multicolumn{4}{|c|}{ Men } & \multicolumn{4}{|c|}{ Women } \\
\hline & \multicolumn{2}{|c|}{$\begin{array}{l}\text { Examined } \\
(N=64)\end{array}$} & \multicolumn{2}{|c|}{$\begin{array}{l}\text { Unexamined } \\
(\mathrm{N}=24)\end{array}$} & \multicolumn{2}{|c|}{$\begin{array}{l}\text { Examined } \\
(N=74)\end{array}$} & \multicolumn{2}{|c|}{$\begin{array}{l}\text { Unexamined } \\
\qquad(\mathbb{N}=28)\end{array}$} \\
\hline & $N$ & $(\%)$ & N & $(\%)$ & $\mathrm{N}$ & $(\%)$ & N & $(\%)$ \\
\hline Hands or forearms only & 14 & $21^{*}$ & - & . & 25 & 34 & 9 & 32 \\
\hline Hands or forearms + other areas & 6 & 9 & 1 & 4 & 28 & $37^{* *}$ & 1 & 4 \\
\hline Trunk or proximal extremities & 17 & 27 & 3 & 13 & 6 & 8 & 3 & 11 \\
\hline Lower legs & 12 & 19 & 2 & 8 & 2 & 3 & 3 & 11 \\
\hline Head or face & 6 & 9 & 3 & 13 & 3 & 4 & 一 & . \\
\hline Toes, toe webs & 2 & 3 & 3 & 13 & 1 & 1 & - & . \\
\hline Area not specified & 7 & $11^{* \star *}$ & 12 & 50 & 9 & $12^{* \star}$ & 12 & 43 \\
\hline
\end{tabular}

${ }^{*} \mathrm{P}<0.05,{ }^{* *} \mathrm{P}<0.01,{ }^{* * *} \mathrm{P}<0.001$ (between the examined and unexamined). 
Table 2. Principal area of dermatoses found in the clinical examination of 138 farmers who reported dermatosis in a questionnaire 6 to 12 months previously. ( $N=$ number of farmers)

\begin{tabular}{|c|c|c|c|c|c|c|c|c|c|}
\hline \multirow{3}{*}{$\begin{array}{l}\text { Principal area of } \\
\text { self-reported dermatosis }\end{array}$} & \multicolumn{9}{|c|}{ Principal area of dermatosis diagnosed by a physician } \\
\hline & \multicolumn{2}{|c|}{ Hands or forearms } & \multirow{2}{*}{$\begin{array}{l}\text { Trunk or } \\
\text { proximal } \\
\text { extremities } \\
(\mathrm{N})\end{array}$} & \multirow{2}{*}{$\begin{array}{l}\text { Lower legs } \\
\text { (N) }\end{array}$} & \multirow{2}{*}{$\begin{array}{c}\text { Face or } \\
\text { scalp } \\
\text { (N) }\end{array}$} & \multirow{2}{*}{$\begin{array}{l}\text { Toe webs } \\
\text { (N) }\end{array}$} & \multirow{2}{*}{$\begin{array}{c}\text { No } \\
\text { dermatosis } \\
\text { (N) }\end{array}$} & \multirow{2}{*}{$\begin{array}{l}\text { Alla } \\
(N)\end{array}$} & \\
\hline & $\begin{array}{l}\text { Alone } \\
(\mathrm{N})\end{array}$ & $\begin{array}{l}\text { Plus other } \\
\text { areas } \\
\text { (N) }\end{array}$ & & & & & & & \\
\hline Hands or forearms alone & 21 & 8 & 1 & 1 & . & . & 8 & 39 & $(28)$ \\
\hline Hands or forearms + other areas & 9 & 13 & 4 & 2 & . & 1 & 5 & 34 & $(25)$ \\
\hline Trunk or proximal extremities & 1 & 5 & 16 & 1 & . & . & . & 23 & $(17)$ \\
\hline Lower legs & $\therefore$ & 1 & 4 & 7 & . & . & 2 & 14 & (10) \\
\hline Face or scalp & . & 1 & 3 & & 2 & 1 & 2 & 9 & (7) \\
\hline Toes, toe webs & . & . & . & 1 & . & 2 & . & 3 & (2) \\
\hline Area not reported & 4 & . & 2 & 1 & 1 & . & 8 & 16 & $(12)$ \\
\hline All ${ }^{3}$ & 35 & $28(20)$ & $30(22)$ & $13(9)$ & $3(2)$ & $4(3)$ & $25 \quad(18)$ & 138 & 100) \\
\hline
\end{tabular}

a Percentage of the total number in parentheses.

Table 3. Dermatological diagnoses in 138 clinically examined farmers reporting a skin disease in the questionnaire survey and the estimated prevalences (\%) in the surveyed farming population (514 men, 448 women). The prevalence of any self-reported skin disease is the point-prevalence (\%) from the questionnaire survey in 1979.

\begin{tabular}{|c|c|c|c|c|c|c|}
\hline \multirow[t]{2}{*}{$\begin{array}{l}\text { Principal diagnosis } \\
\text { (main areas) }\end{array}$} & \multicolumn{2}{|c|}{$\begin{array}{c}\text { Men } \\
(N=64)\end{array}$} & \multicolumn{2}{|c|}{$\begin{array}{l}\text { Women } \\
(N=74)\end{array}$} & \multicolumn{2}{|c|}{$\begin{array}{c}\text { All } \\
(N=138)\end{array}$} \\
\hline & Numbera & $\begin{array}{c}\text { Estimated } \\
\text { prevalence } \\
(\%)\end{array}$ & Numbera & $\begin{array}{c}\text { Estimated } \\
\text { prevalence } \\
(\%)\end{array}$ & Numbera & $\begin{array}{c}\text { Estimated } \\
\text { prevalence } \\
(\%)\end{array}$ \\
\hline Eczema & 34 & 10.8 & 49 & $18.9^{*}$ & 83 & 14.5 \\
\hline Hands only & 7 & 2.2 & 26 & $10.0^{* * *}$ & 33 & 5.8 \\
\hline Hands + other areas & 8 & 2.5 & 15 & 5.8 & 23 & 4.0 \\
\hline Other areas only & 19 & 6.0 & 8 & $3.1^{* *}$ & 27 & 4.7 \\
\hline Psoriasis & 6 & 1.9 & 4 & 1.5 & 10 & 1.8 \\
\hline Miliaria/folliculitis & $5(6)$ & 1.9 & - & $\cdot$ & $5 \quad(6)$ & 1.1 \\
\hline Rosacea & 1 & 0.3 & 2 & 0.8 & 3 & 0.5 \\
\hline Toe-web maceration & $1(3)$ & 1.0 & $2(13)$ & 5.0 & $3(16)$ & 2.8 \\
\hline Tinea in toe nails & - & $\cdot$ & $-(1)$ & 0.4 & $-(1)$ & 0.2 \\
\hline Inguinal intertrigo & 2 & 0.6 & - & $\cdot$ & 2 & 0.4 \\
\hline Pityriasis versicolor & 1 & 0.3 & - & . & 1 & 0.2 \\
\hline Acne & 2 & 0.6 & $-(3)$ & 1.2 & $2 \quad(5)$ & 0.9 \\
\hline Lichen planus & - & $\cdot$ & 1 & 0.4 & 1 & 0.2 \\
\hline Bullous pemphigoid & - & . & 1 & 0.4 & 1 & 0.2 \\
\hline Mycosis fungoides & 1 & 0.4 & - &. & 1 & 0.2 \\
\hline Unspecified pruritus & 1 & $\cdot$ & - & . & 1 & 0.2 \\
\hline Alopecia areata & $-(1)$ & 0.4 & - & . & $-(1)$ & 0.2 \\
\hline All with a skin diagnosis & 54 & . & 59 & . & 113 & . \\
\hline No dermatosis or healed & 10 & . & 15 & . & 25 & . \\
\hline $\begin{array}{l}\text { Questionnaire prevalence of any-self- } \\
\text { reported skin disease in the population }\end{array}$ & 17.1 & . & 22.8 & . & 19.8 & . \\
\hline
\end{tabular}

a Principal diagnoses outside parentheses, in parentheses the total number of diagnoses including secondary diagnoses.

b Estimation of the prevalence: questionnaire prevalence of any skin disease in the population times the number with the specific diagnosis divided by the number of all with any diagnosis.

${ }^{*} P<0.05,{ }^{* *} P<0.01,{ }^{* *} P<0.001$ (all $P$-values between men and women).

months later. Of all dermatoses, $50 \%$ were detected on the same areas the farmers had reported previously.

The diagnoses of skin diseases among the examined farmers are listed in table 3, together with the estimated prevalences in the surveyed population. Eczema was more common for the women ( $83 \%$ of the diagnoses) than the men $(63 \%)(\mathrm{P}=0.03)$. Eczema was on the hands of $84 \%$ of the women and $41 \%$ of the men $(P=0.0006)$ who suffered from eczema, and it had been on the hands in either the questionnaire survey or the examination for $94 \%$ of the women and $47 \%$ of the men. Current atopic eczema was diagnosed in seven cases $(5 \%)$. For five men and eight women who reported hand dermatoses in the survey, the symptoms had healed before the examina- 
tion. Eczema not involving the hands was present on the legs of nine of nineteen men and three of eight women. In the remaining cases eczema was mainly on the trunk. Interdigital maceration was found as the principal diagnosis for one man and two women, and as a secondary diagnosis for two men (total of 3 cases) and 11 women (total of 13 cases).

There were nine women and seven men who had not stated the location of their dermatoses in the questionnaire (table 1). For five women and three men the dermatosis had healed before the examination or the men and women had not had any dermatosis. Two of these women had "rough" hands. The dermatological diagnoses made for the remaining four women and four men with no reported location in the questionnaire were four cases of eczema on the hands, and one of each of a leg eczema, folliculitis, acne, and rosacea.

\section{Validation study}

All of the farmers answering affirmatively to the question of "having a skin disease now" immediately before the clinical examination $(N=41)$ in the validation study were diagnosed as having dermatosis. Of those farmers answering no, $22 \%$ (27 of 122) were diagnosed as having a dermatological disease. Six of these cases of dermatoses were eczema, and three of them were on the hands $(2.5 \%)$. The remaining skin diseases, which were not considered dermatoses by the farmers, were toe-web maceration on the feet in 16 cases, paronychia on the fingers in three cases, acne in one case, and miliaria rubra in one case. A "self-diagnosis" of having "a skin disease now" had, in this validation, high specificity $(1.00)$ but lower sensitivity (0.60).

\section{Discussion}

The prevalences and estimated prevalences of all dermatoses and some specific skin diseases in previous population studies and the present study can be seen in table 4. It is difficult to make comparisons between the studies since the criteria for skin diseases vary. In 1963, Lomholt (1) registered all self-reported dermatoses needing medical attention in a population of 11000 in the Faroe Islands. This is probably the most thorough epidemiologic survey of dermatoses in a specific population. In Lomholt's survey, the prevalence of eczema was only somewhat higher than that of psoriasis (3.2 versus $2.5 \%$ ). The prevalences of all skin diseases or psoriasis have been fairly consistent during the last decades according to the studies listed in table 4 . The prevalence of hand eczema seems to have been much higher in the surveyed occupational groups (5-8) than in general populations $(1,2)$.

The only statistical difference found in the examined group of farmers, when compared with the group not attending the clinical examination, was in the area of

Table 4. Prevalences (\%) and estimated prevalences of some skin diseases in different populations. Some prevalences have been calculated from the figures in the publications.

\begin{tabular}{|c|c|c|c|c|c|c|c|c|c|c|}
\hline Author & Type of population & Number & $\begin{array}{l}\text { Age of } \\
\text { population }\end{array}$ & $\begin{array}{c}\text { Any } \\
\text { skin } \\
\text { disease }\end{array}$ & Eczema ${ }^{a}$ & $\begin{array}{l}\text { Hand } \\
\text { eczema }\end{array}$ & Psoriasis & Rosacea & $\begin{array}{l}\text { Tinea } \\
\text { pedis }\end{array}$ & Acne \\
\hline Lomholt, $1963(1)$ & General population $\mathrm{n}^{\mathrm{b}}$ & 10974 & All ages & 7.7 & 3.2 & 0.2 & 2.5 & 0.1 & . & 0.3 \\
\hline Rea, 1976 (3) & Urban population & 2180 & $\begin{array}{l}\text { Over } \\
15 \text { years }\end{array}$ & $\begin{array}{l}55.5^{c} \\
22.5^{d}\end{array}$ & $\begin{array}{l}9.0 \\
3.5\end{array}$ & . & $\begin{array}{l}1.6 \\
0.6\end{array}$ & . & . & $\begin{array}{l}8.6 \\
3.5\end{array}$ \\
\hline Karvonen, 1976 (4) & Lapp population & 185 & $\begin{array}{l}\text { Over } \\
15 \text { years }\end{array}$ & 25 & 17 & . & 1.6 & . & 2.7 & 1.1 \\
\hline Johnson, 1978 (2) & General population & 20749 & $\begin{array}{l}1-74 \\
\text { years }\end{array}$ & $\begin{array}{l}31.2^{\mathrm{e}} \\
11.8^{1}\end{array}$ & $\begin{array}{l}6.1 \\
2.3\end{array}$ & $\begin{array}{l}0.2 \\
0.6\end{array}$ & $\begin{array}{l}0.6 \\
0.4\end{array}$ & . & $\begin{array}{l}3.9 \\
1.0\end{array}$ & $\begin{array}{l}7.0 \\
2.5\end{array}$ \\
\hline Hirvonen, $1979(5)$ & Bricklayers ${ }^{g}$ & 457 & . & 18 & 9.6 & 7.9 & 1.1 & 0.7 & 7.7 & . \\
\hline Peltonen, $1983(6)$ & Shipyard & & & & & & & & & \\
\hline $\begin{array}{l}\text { Workers } \\
\text { Office employees }\end{array}$ & & $\begin{array}{r}284 \\
71\end{array}$ & . & $\begin{array}{l}23 \\
20\end{array}$ & $\begin{array}{l}17 \\
11\end{array}$ & $\begin{array}{r}10 \\
1\end{array}$ & 0.7 & 0.7 & . & . \\
\hline Peltonen, 1984 (7) & Food industry & 541 & . & 17 & 19 & 11 & 0.4 & 0.4 & . & . \\
\hline Larmi 1988 (8) & Reindeer herders & 211 & . & . & 26 & 9.5 & 0.5 & - & 4.2 & 4.7 \\
\hline Present study & Farmers 9 & 962 & . & 19.8 & 14.5 & 9.8 & 1.8 & 0.5 & $2.8^{\mathrm{n}}$ & 0.9 \\
\hline
\end{tabular}

a All eczema, including atopic eczema, seborrheic eczema, contact dermatitis and neurodermatitis.

- Examined immediately after self-report, cases needing treatment.

- Cases of all grades.

"Moderate to severe cases.

" "Significant skin conditions."

I Skin complaints ("conditions of concern to the individual").

9 Those reporting dermatoses in a survey were examined.

i Toe-web maceration. 
dermatosis (table 1). Of those with self-reported hand dermatoses, $87 \%$ came to the examination. On the other hand, $46 \%$ of those not attending the clinical examination had not specified their dermatosis area in the questionnaire. These facts speak in favor of the concept that those who had a well definable dermatosis attended the examination, and those with more vague problems were not prone to attend.

The diagnoses of farmers with hand eczema, and also the skin test results, have been published elsewhere (15). According to that study, $93 \%$ of the hand dermatoses were eczema, and $70 \%$ were considered work-related. Allergy to cow dander, either in skin prick tests with commercial extract or in a patch test with cow dander as is, was found for $39 \%$ of the tested farmers (15). In the present material, hand eczema was more common for the women than for the men. The finding agrees with the results of many other population studies $(9,10,16-18)$. Eczema had involved the hands or the forearms of most of the women but of only about half of the men with eczema. No significant differences between the genders were found in other diagnoses. The prevalences of eczema $(14.5 \%)$ and hand eczema $(9.8 \%)$, as well as the proportion of hand eczema of all diagnoses $(50 \%)$, were high in this study compared with those of earlier population studies $(1-3)$, but similar to the studies on risk occupations (5-7) (table 4 ). The prevalence of psoriasis $(1.8 \%)$ was similar to the results of other population studies outside Finland $(1-3)$, but higher than in some earlier Finnish studies (5-8) (table 4). In this population, the prevalence of toe-web maceration was low among the men when compared with that of the women (table 3), and also when compared with the prevalence of 'tinea pedis' in some other studies $(2,5,8)$ (table 4). This difference is partly explained by the fact that, in the validation portion of our study, most of the unreported dermatoses (16 of 27 cases) were toe-web maceration.

In the present study, 113 out of 138 farmers were found to have a dermatological diagnosis in the clinical examination 6 to 12 months after a self-report of a skin disease in the questionnaire survey. As seen from the data in table 2, the self-report of the location of the dermatosis corresponded fairly well with the findings in the clinical examination 6 to 12 months later. Of the dermatoses, three-fourths of the cases were found on the same or larger skin areas than those reported in the questionnaire.

In the validation portion of the present study the question of "having a skin disease now" (self-diagnosis) showed that the affirmative answer was very reliable (high specificity), while some of those with a negative answer also had dermatoses (lower sensitivity). This finding agrees with that of other studies $(9,10,12,13)$. In our study, $2.5 \%$ of those who did not report "a skin disease now" immediately before the examination were diagnosed as having hand eczema by the dermatologist. Toeweb maceration was the most common dermatitis not reported by the farmers. It is probable that unreported dermatoses are of minimal concern to respondents.

In Agrup's population study from 1969, 93.5\% of those reporting hand dermatosis in a questionnaire and $1.7 \%$ of those not reporting it were clinically found to have skin changes on their hands (9). Most of the unreported cases of hand dermatoses in Agrup's study were mild eczema. According to Johnson's study (tables 2 and 3 ), the prevalence of clinically diagnosed dermatoses was higher than the prevalence of skin complaints of the individuals. Meding (10) inquired about the respondent's opinion of having had hand eczema during the previous 12 months, and the affirmative answer was confirmed by a dermatologist in $89 \%$ of the cases. Berg \& Axelson (12) clinically evaluated a questionnaire for skin complaints and found high confirmation rates for atopic eczema (0.92), seborrhoeic dermatitis (0.86), and hand dermatoses (0.83), while the rates were lower for acne, rosacea, and skin cancer. A recent Dutch study on nurses (13) validated questions for detecting hand dermatitis in epidemiologic studies. The "self-diagnosis" of hand dermatitis was a good indicator of the presence of it, but also $8 \%$ of those with a negative report were considered to have hand dermatitis by a dermatologist. In the same study, a symptom-based diagnosis of hand eczema detected all of the hand eczema cases (high sensitivity), but for those with a positive diagnosis, there were many without clinically confirmed hand eczema (low specificity).

It is not known how the perception of what a disease of the skin is varies in different populations, times, and cultures. A self-report of a skin disease is probably a good method with which to detect the dermatoses of importance to the respondent. According to this study, shading the dermatosis areas in a picture of a human body seems to be a fairly reliable self-report of the location of a skin disease in questionnaire studies.

Internationally accepted criteria for skin disease epidemiology need to be formed. For diagnosing hand eczema, a combination of a self-diagnosis and a symptombased diagnosis is probably the most reliable. The criteria must be validated in different populations and countries before final approval for standard use is given.

\section{Acknowledgments}

This study has been financially supported by the Social Insurance Institution and the Farmers' Social Insurance Institution in Finland. 


\section{References}

1. Lomholt G. Psoriasis, prevalence, spontaneous course and genetics [dissertation]. Tórshavn: Fröya Fródskaparfelag, 1963. Annales Societatis Scientiarum Færoensis, supplementum V.

2. Johnson M-LT, Roberts J. Skin conditions and related need for medical care among persons $1-74$ years, United States 1971-1974. Hyattsville, MD: National Center for Health Statistics, 1978. DHEW Publication no (PHS) 79-1660. Data from the National Health Survey; series 11; no 212.

3. Rea JN, Newhouse ML, Halil T. Skin diseases in Lambeth. Br J Prev Soc Med 1976:30:107-14.

4. Karvonen J, Sahi T, Kirjarinta M, Tiilikainen A. Skin diseases in a Finnish Lapp population. Nord Counc Arctic Med Res Rep 1976;16:38-43.

5. Hirvonen M-L, Hänninen K, Lehtinen M, Riala R, Riihimäki H. Muuraritutkimus [A bricklayer study]. Helsinki: Työeläkekassa, 1979. LEL Työeläkekassan julkaisuja 3.

6. Peltonen L, Wickström G, Selonen R. Occupational skin diseases in shipyard workers. Derm Beruf Umwelt 1983;31(3):87-91.

7. Peltonen L. Thottumat isossa elintarviketehtaassa [Dermatoses in a large food industry plant]. Työterveyslaitoksen tutkimuksia 2, 1984;3:177-82.

8. Larmi E, Reijula K, Hannuksela M, Pikkarainen S, Hassi J. Skin disorders and prick and patch test reactivity in Finnish reindeer herders. Derm Beruf Umwelt 1988;36:383-5.

9. Agrup G. Hand eczema and other hand dermatoses in South Sweden [dissertation]. Acta Derm Venereol Suppl (Stockh) 1969;61:1—91.
10. Meding B. Epidemiology of hand eczema in an industrial city [dissertation]. Acta Derm Venereol Suppl (Stockh) 1990; 153:1-43.

11. Meding B, Torén K, Karlberg A-N, Hagberg S, Wass K. Evaluation of skin symptoms among workers at a Swedish paper mill. Am J Ind Med 1993;23:721 -8.

12. Berg $M$, Axelson O. Evaluation of a questionnaire for facia skin complaints related to work at visual display units. Contact Dermatitis 1990;22:71-7.

13. Smit HA, Coenraads PJ, Lavrijsen APM, Nater JP. Evaluation of a self-administered questionnaire on hand dermatitis. Contact Dermatitis 1992;26:11-6.

14. Susitaival P, Husman L, Horsmanheimo M, Notkola V, Husman K. Prevalence of hand dermatoses in Finnish farmers. Scand J Work Environ Health 1994;20:206 - 12

15. Susitaival P, Husman L, Hollmén A, Horsmanheimo M, Husman K, Hannuksela M. Hand eczema in Finnish farmers - a questionnaire based clinical study. Contact Dermatitis. In press.

16. Kavli G, Förde OH. Hand dermatoses in Tromsö. Contact Dermatitis 1984;10:174-7.

17. Coenraads PJ, Nater JP, van der Lende R. Prevalence of eczema and other dermatoses of the hands and arms in the Netherlands: association with age and occupation. Clin Exp Dermatol 1983;8:495-503.

18. Rystedt $I$. Hand eczema and long-term prognosis in atopic dermatitis [dissertation]. Acta Derm Venereol Suppl (Stockh) $1985 ; 117: 1-59$

Received for publication: 16 June 1994 